\title{
Reconciling Identity and Citizenship: A Case for Moral Cosmopolitanism in a Divided World
}

\section{Satish Kumar}

\section{Introduction}

This year has been marked with increasing polarisation between communities in UK in particular and the world in general. While terrorist threat levels have sea-sawed through the seasonal changes in the direction of the westerlies, inevitably as global citizens we find ourselves increasingly imbricated into the ever mounting justification for and against the 'veiled' Muslims, be it in France, the UK or Europe. The point is do we want to engage with the politics of 'veil' or a turban? Why is a veil so critical to our existence, our identity? Or is this only an assertion of a political position that group identity is far more important than our individual identity. The only interregnum in this saga of assertion and counter assertion is the alarming discourse around global warming, of international migrants pouring in from Romania and the rise of overcrowding in British prisons. Invariably politics, religion, ethnicity, culture and philosophy tend to get entangled when we attempt to define ourselves in relation to our position in the world in which we live. The dissolution of the erstwhile Soviet Union and Eastern Europe has led to the pre-eminence of capitalism and its democratic liberal principles in place of the ideal of socialism. 'Cultural turn' and its assertion of rights, representation and affirmation of group difference have reinforced new forms of cultural politics and have overshadowed the primacy of individualism and their rights too. Indeed identity is a complicated issue and 
does not lend itself easily to a generalist interpretation. Thus to be identical is very different from sharing an identity (Sen, 2006:xi). The complexity of the term is further compounded when we introduce group versus individual identity.

This paper attempts to evaluate the current debates on identity and citizenship informing our society. It will assess how far global citizenship as a rallying point is capable of informing issues of identity, social, political and thereby infuse a sense of global responsibility to the citizens in the present context. Daisaku Ikeda's assertion that the foundation of all education is learning the path of true humanity will be contextualised in the current debates. This paper makes a case for enforcing the significant ideals of moral citizenship based on the profound respect for each other's common moral platform. The paper asserts that universal human values can only be cultivated through a conscious application of value-based education, which recognises the universality of human rights, of mutual understanding and appreciation of diverse civilisational order, ethnicity and cultures. Is there a space for cultivating a more humane social order based on mutual dialogue, infused by democratic ideals?

\section{Communitarian versus liberal thinkers}

Benhabib (1992:1) notes that "specific aspects of our social, political and symbolic universe have been irretrievably transformed", and in this context the ideas of identity and citizenship too has become highly charged and contested. Over time, three perspectives can be identified which can be associated with identity and citizenship. These relate to communitarianism, liberalism and civic republicanism. Communitarians actually adhere to a strong sense of community. Communitarian ideas relate to a critique of the liberal conception of self or the sovereign individual. They believe that an individual, as a self-centred being cannot contribute to the common good of humanity. However it does acknowledge that the individual is the sole bearer of rights in any given society. Liberalism on the other hand asserts that an individual precedes the polity and citizenship is there to protect the rights of the individual. Therefore liberalism as a concept is far more utilitarian and functional in its engagement with the citizens. In this respect all political systems 
render a service in order to protect the rights of an individual. Kymlicka (1995) notes that modern liberalism has not been very forthright in its dealings with rights of the group.

Protagonists of both communitarian and liberal persuasion appear to be at odds in their conception of the 'individual'. Adherents of liberalism speak about self- promoting individuals, who are constantly ensuring that their rights are protected. Communitarians on the other hand believe that all individuals are situated and embedded and not totally independent and isolated from the community as claimed. As Sandel (1998:150) notes that identity is defined by being a member of a community, just as members of a society are associated with the sentiments and communitarian principles of a given community. In a way, communitarians have always asserted the rights of a group in the making of an identity. They insist that all individuals relate to and imagine themselves to be part of the larger community. In other words an individual's identity is a derived identity dependent largely on their affiliation and indeed their membership to a group. The point is how far individual actions are motivated and transformed by their membership to a community. Individual preferences, i.e. being a practising Muslim or a Jew or a Buddhist can help transcend individual ego to encompass the community of Muslims, or Jews or a Buddhist, especially when they face or sense persecution. We have seen this being deployed in the case of Palestinians, Iraqis, Israelis or Burmese. As Sen (2006) notes, "the idea that one's communal identity is that of self-realisation and not of choice is hard to accept given that we as individuals are constantly making choices and prioritising those choices regarding our affiliations and associations in the society. Identity therefore is a complicated matter" (Sen, 2006, xi).

\section{Identity}

Identity is extremely personal, reinforcing an intense sense of self. At the same time it is associated with our sense of belonging to a group or community and the way one is recognised, classified and acknowledged. Our language, food habits form the cultural markers to distinguish one from the other, us from them. While this gives a sense of cohesiveness, it also reinforces a sense of collective identity. This 
automatically instils a sense of empowerment and links naturally to political and social power. Identity has a special and contentious place in social, political and religious theories. It helps us to present a unified sense of unique self, sharing a given set of beliefs and values. At the same time these very attributes forces us to seek recognition as members of a group in a very political sense. The deliberation for a new found sense of identity calls for the excavation of hitherto silenced and fragile subjectivities. Thus identity does not necessarily have to be rooted in stable social constituencies within the human community. Today identities have become far more ambiguous and hybrid in nature and character. The question is when does identity become an issue? According to Bauman (1996) this becomes an issue when as individuals we are confronted with a sense of uncertainty of our existence. I remember after the Sikh riots in Delhi in 1984, most of the clean-shaven Sikhs took to wearing their turbans and growing their beards to reassert their Sikh identity. Travelling to and fro in the public transport I was acknowledged as a Sikh because of my beard and 'kara' (bangles) even though I was not born a Sikh. Thus identity has "always remained a work in progress” (Taylor and Spencer, 2004:4) and we negotiate this identity every time we meet a new person, or a group, constantly reasserting the spaces of our interaction. It is fair to say that groups who have faced intense cultural and political marginalisation have always attempted to reinstate their identity and citizenship. No matter how 'a political' or rational one may appear, it affects us the way we present ourselves, in the way we dress, speak and how we socialise.

\section{Types of Identity}

Our affiliation to a given group, community or an order influences our identity. Having settled down in the UK, I seek allegiance to my country of origin, India. So I am a person of Indian origin, being born into a Hindu family, and believe in the philosophy of Buddhism. I am an academic and as an intellectual work across a range of social science disciplines, namely, history, economics and geography. As a person born after India's independence, I am conscious of my postcolonial leanings and have no problem engaging with issues of environmentalism, human rights and peace. I am not explicitly opposed to globalisation and 
would prefer its regulation both in the short and long-term across nation-states. So my identity is both simultaneous and collective. It helps to pluralise the perception of my self. Thus my identity impinges on my gender, class, profession, politics and indeed my moral choices. In many ways we may have different kinds of affiliation or membership to societies and groups, which manifest on our identities. A common membership, for example with the United Nations highlights our responsibilities as effective citizens and our relation and responsibilities in dealing with members of the same group. Likewise, we may also have membership of exclusive groups such as professional associations (football clubs) and at the same time may belong to a particular class or gender. Here our identities are very specific and not generic to our membership as a global citizen.

For once the social capital or a sense of belonging to a community can reinforce our identity and thereby our acceptance and participation in society. Indeed, we are constantly making choices about our membership to a particular group at all times. When we become victims of a particular form of politics, we tend to revert back to our primordial affiliation and thereby reinforce our identity as a Hindu, Sikh or a Muslim. The advantage of adhering to a plural identity is that one need not deny an identity for the other. Rather we tend to make informed choices of the relative importance of a given identity particularly during conflictual situations. Consider the following: For the forthcoming UK university-wide Research Assessment Exercise (RAE), I am putting forward my identity as a historical geographer, though I write and teach in the area of development studies too. This is my choice which I ma forced to make in the UK higher education system, to be dovetailed into a pigeonhole. This was not my experience in India and I am sure outside of the UK. As Sen suggests, "identities are robustly plural and that the importance of one identity need not obliterate the importance of others" (Sen, 2006:19). In other words there is no singular identity, which can be ascribed to any one of us. Thus one may be a housewife, a mother, a daughter, a wife, and a senior manager in a firm or a historical geographer, or a development economist or a philosopher (see also Craib, 1998 and Sen, 2006).

Historically, individual identities were always subsumed under 
(210)

the stable moorings of tradition/conventions and were believed to be divinely ordained. This was true of the British monarchy, as of the Japanese or Indian Kings in the early nineteenth and twentieth centuries. The transformations of modernity ushered in by Renaissance of the sixteenth century and of Enlightenment in the eighteenth century clearly helped the individual identity to break free from the shackles of the high church and to a great extent, of the state. For now the individual identity came to occupy the position of primacy and became the touchstone for all forms of scientific progress and transformations in the human society. As Hall states, "rather than see identity as a finished project, we should speak of identification in process, always being formed" (Hall 1996: 122). Globalisation has once again de-centred this individual identity fragmenting it further as a post-modern subject.

\section{Globalisation and Identity}

The radical shifts in transnational diasporic migration in the postcolonial world, of Chinese, Indians or of members of the Northern hemisphere suggest that globalisation has transformed the way we relate to and interact with each other. Identities are about the strategic use of resources such as language (be it English, French or even Dutch), history and culture in order to seek access to the new world. It is very rarely do we find instances of someone seeking to learn Hindi or Chinese to emigrate to India or China particularly as a potential migrant from the developed world. In fact we have come to accept universally that English is the global lingua franca, much to the chagrin of the French. The analysis of transnational migration is always about flows from the developing world. As a result the main outcome of these types of flows is that it raises questions of not just who they are and where they come from, rather it is also about where they are going to and what they represent as a collective, not simply as an individual. Thus the construction of an identity takes place before they are actually represented in any given space. As (Laclau, 1990:3) makes it out that construction and the subsequent representation of a given identity is an "act of power" made either out of consensus or decreed as given.

In post $9 / 11$, George W. Bush can decree that a given identity and all individuals associated with it are the 'axis of evil'. Of course this 
form of rhetoric does not help one to distinguish a brown skinned Indian from a brown skinned Pakistani or a Bangladeshi or a fair skinned Sikh with a customary turban from a Taliban. In many instance mistaken identity has lead to disastrous consequences in USA and UK. I would prefer to be a British Indian than the customary British Asian in order to sit apart from those adhering to a particular faith or code of conduct, or even dress. The conflict we see today is between stable identities trying to come to terms with the constantly changing and fragmented identities in a global world. Modern identities while emphasising uniqueness are no longer unified or wholesome. It comes in various shapes and sizes, choreographed to represent specific politics of culture. In this sense all identities are socially, culturally and historically constructed. Within the Bourdieu (1990) inspired 'habitus', we share common conventions, values, ethics, and practices, which help reinforce our identity and indeed our common citizenship. As Hall (1996) states that it is only in the process of engaging with or giving legitimacy, i.e. recognition or non-recognition, which helps bring to the fore our sense of identity.

\section{Identity formation and its link to citizenship}

In making an analytical distinction between identity and citizenship it is easy to state that identity can be applied to both sentient and insentient beings. Thus we can label nation-state with an identity, just as we can do for a person or even the various regions of the world. A bar code helps to distinguish the identity of a product in a supermarket, much as it would be true for a credit card. Indeed cats, dogs, and indeed all mammals are said to have a personality or an identity unique to their genes. These identities are complex in nature and content. However, over time slippages in these identity formations have come to the fore when there is a perceived threat to identity. The current debate of the 'veil' or hijab in Belgium and in the UK relates to this quandary over identity.

Citizenship as a concept suggests universal entity, which is not tied down to any particular form of identity. As Donald (1996:175) notes, "it is identity-less". The state guarantees the perception of citizenship as enshrined in our constitution and laws of the land. Therefore national identity gives rise to a common ground for citizenship. A sense of 
belonging to the nation helps develop what Anderson (1991) has called the "imagined community". One identifies with being British or American or Indian based on one's allegiance to the flag, national anthem, and cultural symbols of territorial solidarity. However citizenship and rights of a citizen can easily be extended beyond the boundaries of the nation-state. The fluidity of landscapes, particularly 'urbanscapes' in both the developing and the developed world allows for the formation of such citizenship. Globalisation and its attendant transformation of information technology (IT) infrastructure has also led to greater splintering of identities (Graham and Marvin, 2001) and thereby that of common citizenship. It has also aided the closing of the gap across regions of the world in helping form a common and more urgent form of identity.

Global citizenship therefore implies active engagement of concerned citizens and goes beyond the narrow confines of identity. A potential global citizenship transcends nation-state (Taylor and Spencer, 2004: 56). In many ways deliberate exclusion of individuals from the polity and society leads to a fracture in the common identity of a citizen. Inclusiveness has always been extremely critical in bridging the fault lines in identity formation and its related representations. This naturally links to Kant's notion of civil society and of cosmopolitanism. To be able to think of oneself as an individual and at the same time having the capacity to respect others and have empathy for the distant strangers is critical in the formation and establishment of world citizens. As Habermas (1971) notes, "only in a world in which last human being is free and responsible can we too be free". Therefore we have a stake in democracy for all to be free, thereby recognising the freedom of others too. Such a citizenship, which calls for participation has a broader remit than mere political participation within the boundaries of nation-state (Steenbergen, 1994:2). It goes beyond the notion of civil and political rights (Marshall, 1977). Despite the erosion of welfare state over time, we see what Falk (1994) calls a rise of global citizenship, cultural citizenship (Turner, 1994), technological citizenship (Beck, 1996), sexual citizenship (Weeks, 1998) and deep citizenship (Clarke, 1996, for a extended discussion see Taylor and Spencer, 2004: 57).

What are the issues, which help bind people together? It may be 
the appeal for digging deep into our pockets to support the 'red nose' charity for Africa or it may be a collection for the victims of tsunami. What forms the basis for these associations to emerge? Is it faith, love, compassion or a feel good factor or even a determination to be a step ahead of the Jones's? Invariably it is a common tragedy, which galvanises us to act. What spaces will these associations inhabit? It can relate to any region of the world, be it the Amazon forests, the G8 summit, or even the dying victims of HIV in Africa. What emotions and concepts will it appeal to? It may appeal to our sensibility, our emotions of a common humanity, our empathy for those who do not necessarily have the same comforts as us. This goes beyond mere religion, though religious organisation has been active since time immemorial in supporting endeavours during famines and earthquakes (India, Africa or China) or during more recent months in Indonesia and remote parts of Pakistan. Thus the perceived conflict between identity and citizenship can be reconciled with an emphasis on common humanity.

\section{Citizenship and Identity}

Citizenship therefore involves multiple and overlapping perspectives, which cuts across religion, politics, ethnicity, identity and indeed boundaries and territories. Here the rights of a global citizen, of the individual and of the representative group, both of ethnic and religious affiliations can be reconciled if based on a common touchstone of social purpose for a common humanity. For once citizenship is underscored by the fact that we have to take the rights of groups seriously. Both Isin and Wood (1999:ix) refer to the "right to have rights"... as opposed to the passive right of status", which involves a re-conceptualisation of the meaning of identity and citizenship and indeed the means and the ways by which we allocate and recognise rights of a citizen. Thus concept of citizenship gains a wider berth with the recognition of a progressively greater inclusion of various embedded rights in every democratic institution in the world. This also means giving rights to women, gays and the largely dispossessed citizens of the world, either due to the infringement of their political and cultural rights, e.g. of Tibetans or Kurds or due to natural disasters being rendered homeless and destitute, e.g. victims of earthquakes, tsunamis, flash floods and of poverty in Africa and 
(214)

South Asia. Today we have to recognise the victims of global warming, i.e. victims of hurricane Katrina in New Orleans or those battered by endless cycle of cyclones in Bangladesh.

Indeed cultural politics and politics of identity can provide little respite and common nostrum for all the injustices, inequality and oppression facing the world at large. Perhaps a life philosophy, which engenders respect and empathy for the global citizens, will help moralise the actions of self and the others. Citizenship and identity are indeed two sides of the same coin. "The conflict between citizenship and identity arises from a specific conception of each where citizenship is seen as universal and identity as particular" (Isin and Wood, 1999: 2-3). Citizenship entails "loyalty, duties and rights, not always in relation to another human being, but in relation to an abstract concept, the state" (Heater, 1990: 2). As long as citizenship is construed on a common pledge, a common platform of ideals and goals for the happiness of oneself and for the distant others, as much as for one's immediate family will we be able to transcend the conflict between citizenship and identity. Citizenship therefore transcends conflicts of identity based on a moral imperative of empathy, compassion and global justice for the rights of others. The binding glue here is that rights are as important as duties and global responsibilities. Therefore actively participating as global citizens are more important than flagging it as a status symbol.

There is a general belief that citizenship as a concept originated in the west (Weber, 1927) and that civilisations of China, India and Middle East lacked any notion of citizenship. This is a highly ethnocentric, biased viewpoint because each of these ancient civilisations had their own understanding of citizenship. The enshrinement of rights and duties of a citizen in these societies were politically and communally determined. Throughout recent history, we have evidenced the scaling down of civil and political liberties and rights in human societies. The main casualty in all of these has been the notion of citizenship, which has always remained contested as a concept (Turner, 1993). Debates on citizenship have now been polarised along two axes, one, which asserted that individual, is sovereign with inalienable rights and freedom and the other that political association created the rights of the individual. Therefore the individual was seen to be subservient to the state. Today 
rapid integration of global economic space, what Friedman (2005) calls 'The World is Flat', has resulted in a blurring of the boundaries of modern citizenship debate. Increasingly ideas of citizenship as a status and as political entity, embodied within the sovereign individual are being contested. There is increasing attempts to undermine the viability of citizenship by subscribing and confusing it to the narrow sectarian interests of individual rights and associated liberties. The way forward from this imbroglio is that of 'civic republicanism' (Beiner 1995:8) which goes beyond quibbles around issues of liberalism and communitarianism.

\section{Civic Republicanism}

Civic republicanism suggests that citizenship can be effective only if there is a common vision and purpose for action. This action has to be for a common good while pursuing one's individual agenda. The marrying of altruism with individuality becomes the key factor for change. In this respect the blue print adopted by the Buddhist society Soka Gakkai International (SGI) following the footsteps of Daisaku Ikeda $(1998,2006)$ reinforces this dynamic form of civic republicanism. The moral scope for this civic republicanism is immense and provides hope for the millions who attempt to contribute to the creation of value and ethics in their given society and community, based on their sense of absolute happiness. This helps transcend differences of gender, age, ethnicity, religion and indeed nationalities. Citizenship as a concept has to be more than a simple political agenda. It has to be cultural and educational, which reinforces rights and justice in the global world.

The Soka Gakkai International (SGI) therefore attempts to bring to a closure the debates on identity and citizenship by focusing on democratic equivalence among individuals and groups without necessarily eliminating differences among individuals (a la Mouffe, 1995:38). This stresses not the indifference of self-proclaimed individualists, which has caused great deal of problems for the runaway liberalism of the west. In fact Mouffe (1992:226) suggests that the priority of community in civic republicanism is also problematic in that it does not acknowledge the novelty of modern democracy with its principles of pluralism, individual liberty and the separation of church and the state. No doubt this is a 
strong reaction against western concepts of liberalism, however SGI helps to translate these very idea of 'civic republicanism' in reality and practice. Here one need to acknowledge SGIs struggle and eventual liberation from the stranglehold of priesthood, (referred to as 'Buddhist Reformation', Hurst, 2000) has led to the development of a vibrant, democratic civil society among the SGI comrades across the world. The conflict with Japanese Nichiren Shoshu priests was a direct outcome of the desire for SGI opting for a more cosmopolitan outlook in the twenty-first century with respect to the Life Philosophy of the thirteenth-century Japanese Buddhist teacher, Nichiren Daishonin (Machacek and Wilson, 2000; see also Seager, 2006). This has been vindicated with the tremendous expansion and consolidation of SGI global membership under the vibrant and dynamic Daisaku Ikeda's visionary leadership for peace and has succeeded in organising a community around a single idea of common good. At the same time the emphasis on liberty and equality by liberalism cannot be ignored or lost. Thus Soka Gakkai International's endorsement of equality of gender, race, and ethnicity has strong roots in the universal tradition and teachings of Nichiren Daishonin's movement. This can be traced back from the writings of the Lotus Sutra (Watson, 1992 and Max Muller, 1884). Global citizenship is not incompatible with individual liberty if there is a common purpose and so long as the pursuit of the goal of world peace is based on the dignity of life and common interest of humanity.

The advantage from such a philosophy in praxis is that this allows for a universal bond among relative strangers and whose primary allegiance to their ethnic, political or indeed religious community is not seen as conflicting with their membership in Buddhist civil association. This for me is an excellent example of global or world citizenship, which Ikeda has enumerated in the more than four decades of his campaign for a peaceful world based on human revolution. In fact, SGI has incorporated various other cultural activities, in tandem with this perspective, namely Min-On, the Fujii Art Museum, to name a few, which maintains both its 'universitas' (individuals with common purpose or communitarian identity) and its distinctive 'societas' (or individuals with a common purpose or identity) For an extended discussion see Oakeshott, (1975) and Mouffe's, (1995) adoption of this perspective and 
also Carter's, (2001) elaboration of this subject.

The SGI as a community constantly engages with resolving differences through dialogue, consensus and purification of purpose. They define and redefine their common interests. This is based on an old Buddhist concept of oneness of body and mind (shikishin funi) or many in body and one in mind (or itai doshin). This leads to the creation of a revolutionary form of citizenship emerging out of a radical societas. Here the citizen is neither one who is a passive bearer of rights (as in liberalism) nor someone who accepts submission to the rules prescribed by the political association (as in civic republicanism). It reinforces the recognition of multiple subject positions, e.g. demanding gay and ecological rights among others within its membership. Such a radical global citizenship is espoused by the SGI and becomes a democratic basis to present effective political and civic identity, citizenship and leadership.

Following Mouffe $(1995,1992)$ and unlike Isin and Wood (1999), rather than conflating identity and citizenship, the starting point is one of distinctiveness of identity before accepting the membership in a global community. Citizenship here is more a radical social, cultural global identity and not necessarily only a political one. Like Mouffe (1995, 1992) the belief is that race, ethnicity, religion or racial identity can be made subservient to the global identity. Thus for example SGI in India has members from most of the dominant religious groups be it Hindus, who religiously attends to fasting every Tuesday, yet manage to engage with their Buddhist practice on a daily basis and at the same time involves themselves in the movement for peace, culture and education. This in a way translates Mouffe's (1995) perception that race, religion and identity can be subsumed under a global identity without making a special case.

SGIs movement is based on the concept of a common global purpose, which unfortunately is missing while focusing on the highly politicised concept of multiculturalism and inclusiveness prevalent in the political spectrum of UK and the west. SGI philosophy starts with the sovereignty of an individual and of individual happiness. Global collectivism here in SGI is based on a common purpose of working for the happiness of self and that of others. Global citizenship espoused by SGI 
(218)

therefore provides a collective basis to help mediate through conflicting institutions and polity, for example opening up humanity- based dialogues with China and erstwhile Eastern Europe in the late sixties and seventies. SGI indeed celebrates diversity and the unity of purpose to work for peace. It has various groups in place, defining their own identity be it the White Lily Chorus group or the Soka or Lilac group. These form a mosaic of interdependency for spreading the messages of peace and commitment to humanity across the globe.

Thus debates of citizenship inevitably spill over questions of identity. The tension is between those who purport that there are no durable group attributes or those who believe in the need to establish essential attributes of groups. The point we need to remember is that all identities are socially constructed. It is also recognising that stable identities are giving way to fragmented ones and that these new identities are part and parcel of the process of globalisation. Carter (2001) identifies three models of citizenship that: a) which seeks to maximise individual freedom and choice, b) which emphasises moral and political responsibility towards a shared society and c) which focuses on the individual obligations, as well as rights and the value of political activism. All three can be considered as an extended version of global citizenship. I am interested in the third element because it is compatible with a focus on global civil society and cosmopolitan values, which reinforces human rights, global justice and peace. All of these are attainable only if we shun oppression, cruelty and violence. Adherence to international law, to the principles and charters enshrined in the United Nations and our tolerance to religious and cultural diversity will allow space for this moral citizenship to take root in this society.

\section{Moral Citizenship}

Martha Nussbaum (1996) world-renowned moral philosopher has been one of the key supporters of the concept of 'world citizenship' built on the notion of Kant's 'moral cosmopolitanism'. Based on a cosmopolitan approach to education, she encourages us to think about our obligations of respecting distant strangers, as also our own citizens who appear culturally different. She argues for a moral community, which ensures empathy for the common humanity rather than fulfilling mere 
political agendas. This moral community is "one made up of humanity of human beings". These ideas find an echo in Linklater (1996) and Ikeda (2006) writings, urging us to focus on our ethical obligations to the globalised world. Here compassion is an integral part of the rights and responsibilities as a global citizen. Thus moral citizenship and cosmopolitanism reaffirms the rights of individual citizens as much as of the general humanity. How to deal with distant neighbours and strangers? The SGI helps to develop and aspire for true human solidarity based on a foundational life philosophy of Nichiren Daishonin which states that all human beings possess the universal 'Buddha nature' to transform suffering to happiness. Thus a fully developed morality can embrace universal human issues of solidarity. In this sense morality is a universal concept (Walzer 1996: 105). As a global association, SGI helps to induce and promote empathy and allow its membership to imaginatively identify with the 'other'. Our commitment with our neighbour is as important as it is with the distant strangers. Therefore fostering of a global citizenship enables a sense of duty towards future generations. Growing cosmopolitan consciousness engages with the issue of rights and justice at a global level and not confined to a handful few. Such cosmopolitan aspirations have been expressed and practised in the non-western world for many generations and have now moved outside the boundaries of Japan, India and China. The SGI helps to articulate these very same principles of moral citizenship, of empathy, of non-violence, thereby supporting peace initiatives around the world under the aegis of the UN. Ikeda along with Nussbaum believes that global citizenship and indeed the movement for peace, culture and education can be fostered through the medium of education. Individuals working in conjunction with various non-governmental organisations and initiatives help to reaffirm not only their identity as an individual, but also bring forth their sense of global consciousness and moral responsibilities. This helps to reiterate commitment at both the global, local and community levels.

\section{Global citizenship}

Daisaku Ikeda constantly reiterates a perspective of global citizenship in all his writings and speeches that sovereignty resides with the people and not nations alone. In a sense, humanistic education calls 
for the establishment of solidarity of altruism and the widening of a network of truly global citizens (Kumar, 1998, 1996). Humanistic solidarity therefore implies friendship based on a spirit of equality and respect for each other's custom, and traditions (Ikeda, SGINL, 117: 45). The concept of global citizenship has its roots in Tsunesaburo Makiguchi's writings. He stressed the importance of human rights and morality as well as peace and coexistence. Global citizens in a sense are people capable of value creation on a global scale. The essential elements of a global citizen are enumerated by Ikeda (SGINL, 159: 161-64) to have the wisdom to perceive the interconnectedness of all life and living beings. This calls for courage not to fear or deny differences, but to respect and strive to understand people of different cultures and to grow from interactions with them. Soka (or value-based) education provides an opportunity to build up such a courage as well as respect and understanding among diverse cultural representatives.

Therefore the all-encompassing inter-relatedness is the crux of global citizenship and moral cosmopolitanism and reinforces Buddhist ideals of compassion and global justice. The Soka (or value-based) educational system helps in laying the conceptual and ethical foundation for these qualities. It is a vital project in which all are participants and all are accountable for the outcome. Humanistic, value-based education therefore provides a guide to such an exchange and the formation of global citizenship. He calls for "the development of a robust character that can confront the changes in our society without becoming ensnared in greed and selfishness. This kind of robust individuals is rooted in society, in relationship with others and in shared and mutual concerns" (Ikeda 2006: 3). Nussbaum (1996) states that only "through cosmopolitan education, we learn more about ourselves", thereby reiterating what Ikeda (1996) states that education is a noble project to establish a fundamental human attitude of being a world citizen. Therefore values are a product of interaction with life itself and SGIs movement embodies the aspiration to a larger, global harmony.

\section{Acknowledgments:}

To Helen Sharkey and Colin Bird for being around during the 'monsoons of Northern Ireland' and helping me bounce off ideas during 
the drafting of this paper and to my students David Zou and Mathew Kenny for assisting me with key references and discussing the key ideas of 'identity and cosmopolitanism'.

\section{References}

Anderson, B. (1991) Imagined Communities. London: Verso.

Bauman, Z (1996) "From Pilgrim to Tourist-or a Short History of Identity" in S. Hall and

P. Du Gay. Questions of Cultural Identity. London: Sage, pp. 18-36.

Beck, U (1996) "World Risk Society" Theory, Culture \& Society13 (4) pp. 1-32.

Beiner, R (1995) "Why Citizenship Constitutes a Theoretical Problem in the Last Decade of the Twentieth Century", in R. Beiner (eds.) Theorising Citizenship. Albany: State University of New York Press.

Benhabib, S (1992) Situating the Self: Gender, Community, and Postmodernism in Contemporary Ethics. New York: Routledge.

Bourdieu, P (1990) In Other Words, Essays Towards a Reflective Sociology. Cambridge: Polity Press.

Carter, A (2001) The Political Theory of Global Citizenship. London: Routledge.

Clarke, B (1996) Deep Citizenship. London: Pluto.

Craib, I. (1998) Experiencing Identity. Boston: London

Davis, J.E (2000) Identity and Social Change. New Brunswick: Transaction Publishers.

Donald, J (1996) “The Citizen and the Man About Town”, in Hall, S and Du Gay, P. (1996) Questions of Cultural Identity. London: Sage, pp. 170-190.

Falk, R. (1994) "The Making of Global Citizenship", in B. van Steenbergen (eds.) The Condition of Citizenship. London: Sage, pp. 127-140.

Friedman, Thomas (2005) The World is Flat: A Brief History of the Globalized World in the Twenty-First Century. London: Allen Lane.

Graham, S and Marvin, S (2003) Splintering Urbanism: Networked Infrastructures, Technological Mobilities and the Urban Condition. London: Routledge

Habermas, J (1971) Theory and Practice. London: Heinemann.

Habermas, J (1994) "Citizenship and National Identity", in B. van Steenbergen (eds.) The Condition of Citizenship. London: Sage, pp. 20-35.

Hall, S and Du Gay, P. (1996) Questions of Cultural Identity. London: Sage.

Hanagan, M. (1997) "Recasting Citizenship: Introduction". Theory and Society, vol. 26, no. 4, pp. 397-402.

Heater, D (1990) Citizenship: The Civic Ideal in World History, Politics and Education. London: Longman Group.

Hurst, J. (2000) "A Buddhist Reformation in the Twentieth Century: Causes and Implications of the Conflict between the Soka Gakkai and the Nichiren Shoshu Priesthood", in D.W. Machacek and B. R. Wilson (eds.) Global Citizens: The Soka 
Gakkai Buddhist Movement in the World. Oxford: Oxford University Press, pp. 6796.

Ikeda, Daisaku (2006) A New Era of the People: Forging a Global Network of Robust Individuals. SGI, Japan.

Ikeda, Daisaku (1998) Humanity and the New Millennium: From Chaos to Cosmos. Tokyo: SGI publications.

Ikeda, Daisaku (1992) SGI News Letter, No. 117: 45

Ikeda, Daisaku (199*) SGI News Letter, No. 159: 161-64

Ikeda, Daisaku (199*) SGI News Letter, No. 159: 65-66

Isin, E.F. and Wood, P.K. (1999) Citizenship and Identity. Sage: London

Kumar, M.S. (1996) "Civil Society and the State: A Case for Religious Versus Secular Rights in Contemporary Japan”, Bulletin of the Institute of Oriental Studies, no. 12, pp. 135-149.

Kumar, M.S. (1998) "An Approach Towards World Citizenship in the Context of Soka Educational Perspective" Bulletin of the Institute of Oriental Philosophy, No. 14, pp. 100-114

Kymlicka, W (1995) Multicultural Citizenship. Oxford: Oxford University Press.

Laclau, E. (1990) New Reflections on the Revolution of Our Time. London: Verso.

Linklatter, A (1996) "Citizenship and Sovereignty in the Post-Westphalian State". European Journal of International Relations, vol. 2, pp. 77-103.

Machacek, D.W. and Wilson, B.R. (2000) Global Citizens: The Soka Gakkai Buddhist Movement in the World. Oxford: Oxford University Press.

Marshall, T. H (1977) Class, Citizenship and Social Development. Chicago: University of Chicago Press.

Mouffe, Chantal (1995) “Democratic Politics and the Question of Identity”, in J. Rajchman (eds.) The Identity in Question. New York: Routledge.

Mouffe, Chantal (1992) Dimensions of Radical Democracy: Pluralism, Citizenship, Community. London: Verso.

Mouffe, Chantal (1992) "Democratic Citizenship and the Political Community", in Chantal Mouffe, (eds.) Dimensions of Radical Democracy: Pluralism, Citizenship, Community. London: Verso.

Max Muller, F (1884) The Saddharmapundarika: The Sacred Books of the East, vol. 21, translated by H. Kern. India: Motilal Banarasidass (1989 edition).

Nussbaum, Martha, C. (1996) "Patriotism and Cosmopolitanism", in Nussbaum, M.C. et. al., For Love of Country: Debating the Limits of Patriotism. Boston: Beacon Press.

Oakeshott, M (1975) On Human Conduct. Oxford: Oxford University Press.

Sandel, M. J. (1998) [1982] Liberalism and the Limits of Justice (2 ${ }^{\text {nd }}$ edn) Cambridge: Cambridge University Press.

Seager, R.H. (2006) Encountering the Dharma: Daisaku Ikeda, Soka Gakkai, and the Globalisation of Buddhist Humanism. Berkeley: University of California Press.

Sen, Amartya (2006) Identity and Violence: The illusions of Destiny. Allen Lane. London. Taylor, G and Spencer, S. (2004) Social identities: Multidisciplinary approaches by 
Routledge: London.

Turner, B.S. (1994) "Postmodern Culture/Modern Citizens", in B. van Steenbergen (eds.) The Condition of Citizenship. London: Sage, pp. 153-168.

Turner, B.S. (1993) Citizenship and Social Theory. London: Sage.

Turner, B.S. (1993) “Contemporary Problems in the Theory of Citizenship”, in B.S. Turner (eds.) Citizenship and Social Theory. London: Sage.

Van Steenbergen, B. (1994) The Condition of Citizenship. London: Sage.

Weber, Max (1927) 'Citizenship’, General Economic History. London: George Allen \& Unwin.

Weeks, J (1998) “The Sexual Citizen”. Theory, Culture \& Society. Vol. 15, Nos. 3/4, pp. 3552.

Walzer, M. (1996) "Spheres of Affection", in Nussbaum, M.C. et. al. (eds.) For Love of Country: Debating the Limits of Patriotism. Boston: Beacon Press.

Watson, B (1992) The Lotus Sutra. Columbia: Columbia University Press.

(サティッシュ クマール・海外研究員) 


\section{Reconciling Identity and Citizenship: A Case for Moral Cosmopolitanism in a Divided World}

\section{Satish Kumar}

Science has invariably been valued as a means to know the world. However today with the advancement of technology, science is now more than ever used to change the world we live in. The outcome of this perceptible change in approach was that there is precious little recognition for the universal values of education, of mutual coexistence of all life forms. At a quantum level however there is interconnectedness of all forms, both sentient and insentient objects.

This paper attempts to evaluate the current debates on identity and citizenship informing our society. It will assess how far global citizenship as a rallying point is capable of informing issues of identity, social and political and thereby infuse a sense of global responsibility to the citizens in the present context. Daisaku Ikeda's assertion that the foundation of all education is learning the path of true humanity will be contextualised in the current debates. This paper makes a case for enforcing the significant ideals of moral citizenship based on the profound respect for each other's common moral platform. The paper asserts that universal human values can only be cultivated through a conscious application of value-based education, which recognises the universality of human rights, of mutual understanding and appreciation of diverse civilisational order, ethnicity and cultures. Is there a space for cultivating a more humane social order based on mutual dialogue, infused by democratic ideals? 